\title{
CREATING GLOBAL DEMAND: POLYCENTRIC APPROACHES, CROSSROADS OF SILK AND SILVER IN CHINA AND IBERIAN EMPIRES DURING THE EARLY MODERN ERA*
}

\author{
MANUEL PÉREZ-GARCIA @ \\ Shanghai Jiao Tong University ${ }^{\mathrm{a}}$
}

\begin{abstract}
This monographic issue of the RHE-JILAEH presents new case studies in order to compare regions of Asia, Europe and the Americas through analysis of global demand for western goods in China (goods of European and American origin) as well as demand eastern goods (of Chinese and Indian origin) in Europe and the Americas. The global circulation of goods included accumulation of American silver in the hands of Chinese merchants and private institutions. Thus, this issue re-evaluates origins of the first globalisation during the $16^{\text {th }}$ century, as opposed to the 1820s. Global trade networks and long-distance alliances in Asia, the Americas and Europe date back to the $16^{\text {th }}$ century when Manila galleon routes were established.
\end{abstract}

Keywords: global history, Americas, China, Europe, silver, commodity demand and supply

JLF Code: N01, N85, D12, N33, N35, P33

* This monographic issue is the result of the panel «Beyond the Silk Road: The Silver Route and the Manila-Acapulco Galleons for the Global Circulation of Goods and People in China, Europe and the Americas» organized by GECEM Project at the XXXVI International Congress of the Latin American Studies Association (LASA)/Latin American Studies in a Globalized World held in Barcelona, Spain, 23-26 May 2018. It is also a result of the panel «Social Network Analysis and Databases for New Comparative Global History Studies in China, Europe, and the Americas» organized by the GECEM Project at the XVIII World Economic History Conference/Waves of Globalization held in Boston, USA, July 25 to 3 August 2018.

${ }^{a}$ Department of History, School of Humanities, Shanghai Jiao Tong University/P.I. of GECEM Project (ERC-StG.679371), manuel.perez@eui.eu; mpergar@sjtu.edu.cn 


\section{RESUMEN}

Este número monográfico de la RHE-JILAEH tiene como objetivo introducir nuevos casos de estudio que tratan de comparar regiones de Asia, Europa y las Américas mediante el análisis de la demanda global de productos occidentales en China (de origen europeo y americano), así como la demanda de bienes orientales (de origen chino e indio) en Europa y América. La circulación global de bienes de consumo conllevaba como principal característica una constante acumulación de plata americana en manos de comerciantes chinos e instituciones privadas. Por lo tanto, este número monográfico reevalúa los orígenes de lo que se ha considerado una globalización temprana a lo largo del siglo XVI, en contraste a las tesis que defienden que la primera globalización surgió durante la década de 1820. Las redes de comercio global y las alianzas de larga distancia entre comerciantes en Asia, América y Europa se remontan al siglo XVI cuando se establecieron las rutas del galeón de Manila.

Palabras clave: historia global, América, China, Europa, plata, demanda y oferta de bienes

\section{THE «NEW» GLOBAL HISTORY vs. THE IMAGINARY OF THE «SILK ROAD»}

Global historians study and compare various socio-economic areas of Asia, Europe and the Americas. One aim is the analysis of divergent paths of modern economic growth in western and eastern areas. The California School, and a new generation of global historians, has challenged Eurocentric approaches commonly used to study the process of globalisation and market integration within the framework of the great divergence debate. Papers presented in the current issue provide new empirical evidence concerning global demand for Asian goods, wealth accumulation and flows of American silver to Asia through concrete case studies that connect East Asia (China, Macao, Japan, the Philippines) and India with the Americas.

The role of the Americas in context of market integration and global demand for Asian goods (such as Chinese silks and Indian cottons) in the West should be further explored through analysis of maritime «Silk Road» connections to the Americas via Manila galleons; and viceversa, American silver exchanged for Asian commodities. A new generation of global historians stresses the importance of commercial connections and trade networks established between Asia and America by pondering roles played by commodities traded throughout the vast Pacific Ocean. Concrete case studies might demonstrate that the process of globalisation 
took place during the early modern period, through economic and sociocultural interactions involving Eurasian polities. Thus, early globalisation did not occur in the 1820s through price convergence, as a sole indicator for market integration, as some economic historians believe (O'Rourke and Williamson 2004), but rather during the $16^{\text {th }}$ century (De Zwart and Van Zanden 2018; Flynn and Giráldez 2008).

The formative process of trade networks that integrated Pacific and Atlantic markets took place during the $16^{\text {th }}$ century when ManilaAcapulco trade routes were established, and in the context of Iberian union when the kingdom of Portugal and the Spanish crown were unified under Spanish Habsburg monarchs (Elliot 2002; Yun-Casalilla 2019). The $18^{\text {th }}$ century created a new scenario in the international order and political systems with the arrival of Bourbons to the Spanish throne after the Succession War, as French merchants and the Mediterranean market gained hegemony to the detriment of Italian merchants who played an important role in Atlantic fleets and Carrera de Indias. French traders took over in local markets of Canton, Macao, Manila, Lima-Callao, Acapulco, Buenos Aires, Cadiz-Seville, Marseille, among other relevant nodes of trade. The Mediterranean market system was juxtaposed in South China and Philippines, through long-distance partnerships and family networks (Gipouloux 2011), in what might be called the "Asian Mediterranean brokerage system». Merchants, mainly sangleyes (Chinese merchants in Manila), were the main socio-economic agents acting as mediators in a brokerage system that integrated western and eastern markets rising due to demand for overseas goods and silver accumulation.

Neither Chinese historiography on one side nor European and American historiography on the other side, has dealt with this topic through cross-referencing of western and eastern sources. Thus, discussion of Manila galleons and trade between China and the West has been biased. Use of partial empirical evidence has somehow obscured results, thereby rendering analysis fragmentary. Pacific trade routes have been mainly studied as round trips between Acapulco and Manila (Yuste Lopez 2007; Bonialian 2014; Suarez 2018) without provision of further evidence and analysis concerning trade nodes, agents and business alliances between local elites of Manila and sangleyes with Hong merchants of Canton (Van Dyke 2016) and western companies that operated in South China seas. European historiographies have neglected American nodes and connections in favour of analysis of trade and circulation of European (western) goods in South China. This is mainly explained through Eurocentric perspectives dominated by Anglo-Saxon supremacy, limited to the analysis of the British world and its colonies. There has been a revival of Spanish and Latin American historiography in recent years, however, that seeks new comparisons (Hausberger and Ibarra 2014; Perez-Garcia and de Sousa 2018; Suarez 2018; Yun-Casalilla 2019). 
There have been outstanding contributions aimed at rewriting the economic history of China and its economic development compared with the West. The California School mainly the works by Gunder Frank, Pomeranz (2000) or Bin Wong, among others, have challenged the so-called Eurocentric views. Nonetheless, the discipline of global history has resulted in strong divisions among Chinese historians. The classic Marxist school rejects this discipline as they perceive global history as a disperse and heterogeneous narrative marked by western thinking, a sort of «neocolonial» strategy that might contaminate the concept and meaning of Chinese history, culture and civilisation (Wu Xiaoqun 2005; Yu Pei 2006; Li Qiang 2011). As a consequence of this predominant trend in Chinese historiography, studies that compare China with the Americas or Europe are scarce almost to the point of non-existence. Most studies focus on the uniqueness of the history and civilisation of China. The very concept of civilisation is old-fashioned by now, but nevertheless widely used in Chinese academic and political circles. It is an element of current policy-making of China, with connotations of the Cold War period (Toynbee 1934). This has resulted in a paltry number of practitioners of global history in China (Liang Zhanjung 2006; Liu Xincheng 2012).

Putting aside Eurocentric and Sinocentric perspectives is imperative because the implementation of the new global history requires decentralised case studies that consider American, Asian and European regions via polycentric approaches. The maritime «Silk Road» is a geographic unit of comparison that emerges in studies presented in this volume, whereby goods, silver and merchants circulated across Eurasian and American cultures. It served as an artery for global trade between South China ports in Guangzhou, Fuzhou, Xiamen, Mingzhou, among others, and the West (Li Qingxin 2018). Macao was a linchpin that connected western regions with China. Recent scholarly «Silk Road» works in fashion embody a rigid national and domestic mission to rewrite Chinese history

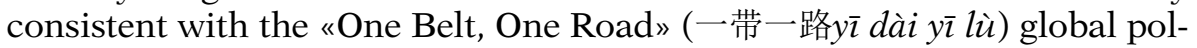
icy of the Chinese government (Liu 2010; Perez-Garcia 2016).

The exceptional culture, history and language of China are the main features of the Sinocentric perspective portrayed by practitioners of global history in China. Chinese exceptionalism advanced in such global histories, however, is embedded in illusion conveyed through images designed to portray the land and maritime «Silk Road» as a continuum resulting in present day patriotic and national values in China through its culture. The «Silk Road» ended in 1524 according to Li Bozhong (2017), however, when the Ming court closed the door to the West through the location of seven border garrisons (Guanxi Seven Garrisons 關西七衛) in northwestern regions, thereby closing trade with the West across Eurasia: «Close the door [to the barbarians in West China] and suspend the tribute 
trade [with them], and never have dealings with them (閉關絕貢, 永不與通 bìguān jué gong, yǒngbù yú tōng)» (Li Bozhong 2017).

After the end of the "Silk Road» in the mid- $16^{\text {th }}$ century, Chinese land trade shifted toward rapidly increasing maritime trade. Land trade was riskier and with higher costs, rendering maritime trade a more profitable alternative. Although maritime trade was more lucrative, it was also more difficult to control by Ming and Qing officials, leading to the long-run decline of the Chinese economy as the Qing state proved inefficient in the management of maritime trade in South China (Deng 1999). State revenues were diverted to private merchants and local gentry, and therefore corruption increased. Manila galleons opened during this period, thereby propelling maritime trade was a major route through which heavily demanded American silver bars and coins could enter Chinese markets. Robust demand for American silver stimulated corruption and smuggling problems, as can be observed in cases presented throughout this volume. It is important to note the historical context of the Iberian union of crowns that facilitated the formation of trade networks among European (mainly Portuguese and Spanish) and Chinese merchants. Activities within these networks escaped supervision of Qing officials, as demonstrated throughout this special issue.

Comparative and connected history, as well as cross-referencing of sources, emerges as a major research tool utilised throughout case studies presented herein, adding substance to comparative and connected aspects of the so-called «new» global history (O'Brien 2006; Drayton and Motadel 2018). A current scholarly criticism of global history, that it merely offers overly ambitious and rhetorical narratives, is deconstructed in this issue. This is accomplished through a combination of new theories/hypotheses alongside new data mining; this combination presents insights into the influence of local socio-economic forces upon the process of global market integration. Use of scattered sources, in conjunction with social, economic and cultural features, provides new tools through which to implement the «new» global history.

«New» global history articles presented herein contest the straightjackets of Eurocentric and Sinocentric perspectives, instead of combining wide sets of eastern and western sources. It challenges rigid approaches of economic historians, social historians and others who restrict analysis of global market formations within limits of single respective disciplines. We advocate interdisciplinary perspectives. Integration of economic theory with detailed analysis and source criticism by economic and social historians (just to mention a few sub-fields that should be integrated) should become a common agenda for the "new» global history. Again, use and analysis of sources in several languages is another important element to incorporate in such agenda. Within limits of their respective cases, papers of this special issue of the RHE-JILAEH stress the importance of reviewing 
global history, and comparisons between China and the West, through fresh ideas.

\section{GLOBAL DEMAND FOR CHINESE GOODS AND SILVER ACCUMULATION IN CHINA}

Accumulation of American silver in China during late Ming and Qing dynasty is viewed by Jin Cao and Dennis Flynn through evidence provided by wealth confiscation records involving officials and gentry family possessions. Wealth accumulations involved, in part, of family networks engage in South China trade and alliances with local merchants of Canton and Fujian. Such networks included provincial officials who bypassed institutional channels and diverted revenues to private pockets.

Contraband and smuggling activities involving exchanges of Chinese goods (e.g. silk, tea and porcelain) for American silver are not reflected in official documents, so studies of the Manila galleons (Chaunu 1962; Yuste Lopez 2007) could only partially assess the quantities involved. For instance, almojafigazgo taxes have been thoroughly studied, but ignore huge smuggling trade of South China seas. This issue was recognised by local officials in Manila, which led the Spanish crown to grant more licenses to sangleyes to partly mitigate the growing problem of illegal trade.

Reliance upon almojarifazgo taxes has biased conclusions; for instance, scholars have claimed that a rise in almojarifazgo taxes caused Chinese imports into New Spain to subside. This conclusion ignores smuggling activities, however, and a rise in licenses issued to sangleyes provides an indirect indication of the increasing problem of contraband trade. Institutions of the Spanish empire were not able to solve this problem. Flynn and Giráldez (2008) demonstrate that flows of American silver rose, as did Chinese silk exports into New Spain via Manila (Boxer 1958), in the form of contraband in response to rising almojarifazo taxes.

Jin Cao and Dennis O. Flynn cite historical evidence indicating that ships from Macao and Canton to New Spain, via Manila, were loaded full of silk cargoes far above legally permitted levels. Confiscations records in sources at Archivo General de Indias (Spain) and Archivo General de la Nacion (Mexico) also provide clear evidence of substantial smuggling activities involving flows of American silver into China and counter-flows of Chinese silks to the Americas and Europe.

Analysis of Pacific trade that connected the Americas, via Manila, to South China, should move beyond classic assumptions of flows of Chinese goods and silver reflected in official institutions and tax data (almojarifazgo), which certainly correspond neither with fluctuations in demand for Chinese goods nor end-market demand for American silver. Cross-referencing sources from China and western archives provide a 
more accurate picture of such flows through «unofficial» institutions and long-distance partnerships among Chinese, American and European trade companies.

The port of San Blas (located in the Intendencia of Guadalajara in Pacific coast of New Spain) stands out as an «unofficial» linchpin of contraband (Hausberger and Ibarra 2014) exchange of American silver for Chinese silks along the so-called «silver route» of New Spain. The same applies to South American routes via Lima-Callao in Peru (Suarez 2018), as well as Cape Horn connections to Montevideo and Buenos Aires. Overland distribution networks from the Andes (Peru and Chile) to the viceroyalty of Rio de la Plata and its local connections with Montevideo, Asuncion del Paraguay and Brazil were active. This route is thoroughly analysed in Antonio Ibarra's paper, representing sources in the Archivo General de Indias (Spain), Archivo General de la Nacion (Argentina) and Archivo General de la Nacion (Uruguay), which documents navigation from India, China and Philippines of vessels loaded with Asian goods, mainly a wide array of silks. Ibarra's research focuses upon the supply side, non-freight goods (comercio de pacotilla) and how this affected demand for Asian commodities. The structure of local supply, and small networks of retailers, was integrated with global demand.

In this context, it is important to remark on the failure of Spanish institutions, such as the Real Compañia de Filipinas, due to high company costs, as well as the fragility of its economic resources. Small trade companies, in partnership with big trade houses such as the Landeiro, Perez, Grill, Roux, 潘 Pan family of Canton, among others, acted outside the realm of official institutions. This is consistent with the intensification of trade relations among Asia, America and Europe. Trade zones of Lisbon, Cadiz-Seville and Marseille were end-markets but also points of transit through which Asian goods were purchased by local retailers and distributed through networks of urban and rural consumers where end-market demand already existed. The urban area of Seville is a good example of end-market customers for Asian goods, silks, porcelains and a wide typology of Asian furniture and adornments, as demonstrated in the paper by Manuel Perez-Garcia based upon a sample of probate inventories for the urban area of Seville. This methodology shows local preferences and changes over time in purchase of Asian goods. Consolidated local demand for Asian goods in Seville increased during the $18^{\text {th }}$ century, rendering Seville an outstanding European example of an end-market (Flynn 2019) for Asian goods that arrived via East Asian and American trade routes.

These flows of Asian goods, mainly silks, to end-market destinations, indirectly demonstrate large accumulations of silver by local merchants in China, as mediators/agents for exchanges, as well as end-market customers. Supplies for export goods were affected by price volatility and capacity to reduce trade risks. Risk reduction, mainly maritime, was 
extremely important in markets of South China (see debt accumulation by the Santa Casa de Misericordia de Macao analysed by Manuel Perez-Garcia), and depended upon consolidation of trade networks, trust and information shared among partners in Macao-Canton, Manila and American markets in Lima and Buenos Aires. This communication factor ensured the successful arrival of cargos at local markets, which of course impacted local stocks of Asian goods in American and European markets. Trust and information shared among partners influenced local accumulations of stocks in relation to demand-side capacity to absorb stocks of goods, thereby helping parties to better anticipate price volatilities. In local markets of Canton depicted in Manuel Perez-Garcia's paper, increased demand for European wines and liquors led local suppliers to raise the price of wine three or four times higher than its price in local (export) markets of Cadiz. Similarly, low prices for low-quality silks (manufactures in Nanjing or Suzhou) exported to western markets (high-quality silks mainly remained in local Chinese markets) induced high-volume purchases by European and American trade companies that then sold them in American and European markets at elevated prices.

Antonio Ibarra's paper demonstrates the importance of trust and access to the information within the Letamendi-Funes-Sarratea partnership in Buenos Aires, as reflected in exchange of internal letters. Many times information received was incomplete, in which cases they depended upon external agents to ensure cargoes could be sold profitably at good prices. Trust and access to good information indicate the fragility of the Real Compañia de Filipinas and why official institutions depended upon individual agents, and small networks of trade partners in South China seas, as well as in local American and European markets, local actors who were the real drivers of the Pacific trade. Costs and interest rates faced by the Hùbù 户部 or Hoppos in Canton, and sangleyes and small trade company associations in Canton, Macao and Manila were key issues that explain speculation and highly fluctuating prices for goods imported into China, as well as Chinese goods exported to American and European markets. For this reason, it is a challenge to reliably convert currencies and make econometric approximations concerning the price convergence thesis that, according to O'Rourke and Williamson (2004), was the single factor that determined market integration in 1820. According to data and cross-referencing sources presented in this volume, the price convergence thesis underestimates the significance of the brokerage system and unregulated markets that relied upon actions of private local merchants. Local supply-demand conditions, price fluctuations, silver stocks/flows and wealth accumulation generally depended upon local traders, mainly the Hoppos, and officials in Canton, a key issue that requires further examination. The Real Compañia de Filipinas and the Canton System一口通商ȳ̄kǒu tōngshāng, institutions respectively established by the Spanish and Qing empires in the second 
half of the $18^{\text {th }}$ century, indicate failure to regulate stocks and flows of goods (including silver) throughout Pacific markets.

Jin Cao and Dennis O. Flynn offer a methodology designed to estimate the quantities of silver stocks and silver flows via both legal and illegal trade systems. They begin with a fanciful assumption-not an estimatethat the silver stock for all of China equalled 15,000 tons in 1750. The purpose of this hypothetical initial number is simply to show how stocks and flows of silver interact within their model, prior to the introduction of archival evidence that reflects actual silver accumulations revealed in documents. Sources used by Cao and Flynn are provincial treasuries of Imperial Household Department (內務府Nèiwù fŭ ) and private households. Their research attempts to depict silver holdings within China as a specific aspect of a global history of wealth (all accumulated goods). This exercise represents an initial attempt to more accurately estimate the stocks of silver held within China at particular points in time on the basis of archival evidence, a new approach to this research issue. Cao and Flynn utilise Chinese "confiscation archives» in which official reports indicate significant silver holdings (along with other household assets), irrespective of whether these silver accumulations originated through legal or illegal trade channels. Local gentry and officials accumulated fortunes through both legal and illegal trade sources, and many of these confiscation targets became wealthy through corruption. The corrupt Héshēn 和珅 official is cited as a notorious example. A robust sample of about 2,500 cases of official and gentry household assets confiscations range over a long period from 1700 to 1900 during which the Qianlong reign, when Canton System 一口通商yīkǒu tōngshāng was imposed, proves to be a period of particular corruption.

Market integration between Pacific and Atlantic Oceans is characterised by rampant contraband, flows of silver drained to East Asia in exchange for silk to Americas and Europe, through overland linkages between Lima-Callao and Buenos Aires across the Andes. This was the main trade route not only for exchanging silver for Chinese goods (mainly silks), but also for purchase of African slaves. As Lucio de Sousa demonstrates through analysis of judeo-conversos trade networks that connected Macao-Japan, Macao-Japan-Philippines, Japan-Philippines, MacaoPhilippines-Acapulco, the main goods exchanged among these markets were silks, tea, porcelain, slaves and silver. The Landeiro, Perez or Rodriguez families (de Sousa 2010) are notable participants in such trade.

The credit-mercantile system that integrated local markets of South China (Macao-Canton) with the Philippines (Manila), Americas (Acapulco, Lima-Callao, Buenos Aires) and Europe (Cadiz-Seville, Marseille) is characterised by a hybrid structure of official institutions and unofficial institutions and agents connected to them. Trade agents involved in institutions, such as the Santa Casa de Misericordia de Macao (Holy House of Mercy), 
the Compañia de Jesus (Society of Jesus) and Manila galleons connected with local elites and brokers, created an uncontrollable economic system that bypassed regulations established by Qing officials of South China and Spanish institutions that intended to monopolise the Pacific trade via Manila. A brokerage system of small trade houses was composed of sangleyes in the Philippines, Hong merchants in Canton and European (mainly Portuguese) traders that operated in Macao covered by religious institutions such as the Casa de Misericordia de Macao or the Compañia de Jesus. Manuel Perez-Garcia demonstrates these connections via the high volume of trade debts that the Casa de Misericordia de Macao incurred during the last quarter of the $18^{\text {th }}$ century while financing maritime trade and insurance in South China seas. In similar fashion, analysis by Lucio de Sousa presents contracts and credit letters of Compañia de Jesus members showing that they acted as trade agents. This hybrid brokerage and credit system allowed European traders to operate in Chinese markets, including elevated prices for European goods such as wines or liquors introduced in high volumes to the markets in Canton and Macao, while receiving allotments to procure volumes of silk, porcelain and tea that in many cases exceeded permitted freight limits of vessels.

It is not possible to understand trade relations among unregulated markets that connected South China with the Americas via the Philippines without recognizing negotiations and alliances between local elites of Manila (i.e. governor of Manila don Diego de Ronquillo, 1583-1584, or governor of Manila don Simon de Anda y Salazar, 1770-1776) and trade networks of sangleyes and judeo-conversos. Early formation of such networks dates from Portuguese arrival in Macao during the $16^{\text {th }}$ century. Lucio de Sousa demonstrates the foundations of such alliances through the families Landeiro, Jorge and Moxar. Manuel Perez-Garcia goes on to show continuity and consolidation of such alliances in the $18^{\mathrm{th}}$ century between local elites of Manila, led by the governor don Simon de Anda y Salazar, with Hong merchants of Canton (mainly the 潘Pan family) and trade companies that operated in Europe and the Americas, that is, the Swedish Grill company and the French Roux company.

Royal prohibitions and attempts to regulate trade through Iberian institutions during the $16^{\text {th }}, 17^{\text {th }}$ and $18^{\text {th }}$ century did not prevent the continuation of unofficial practices. Actions of private merchants and unofficial institutions were a prominent feature of trade in East Asia and Southeast Asia during the early modern period. The paper by Lucio de Sousa indicates a strong trans-national component to European shipping, as Portuguese ships were indeed commanded by Portuguese captains, but in fact ships and cargoes originated from India, Southeast Asia, China, as well as Cambodia, Thailand and Cochinchina. Macao and Manila were the main trade nodes that connected economic relations among these areas. Rich sources in historical archives of Portugal (Arquivo Nacional Torre 
do Tombo), Spain (Archivo General de Indias), Mexico (Archivo General de la Nacion), Macao (Arquivo Historico de Macau) and Manila (Historical Archives of Manila) allow us to analyse and quantify ship voyages, origins, cargoes and socio-economic components of crews. Accurate approximation of networks and business partnerships can be developed, as demonstrated in papers by Lucio de Sousa and Manuel Perez-Garcia.

Increasing numbers of Portuguese and Spanish families in Manila, Macao and Nagasaki during the $16^{\text {th }}$ and $17^{\text {th }}$ centuries cannot be understood absent the concept of conversos (converts to Catholic confession), a predominant feature of Iberian families who settled down in East Asia and Southeast Asia to escape from the Spanish and Portuguese Inquisitions. Lucio de Sousa analyses social components of trade networks in East Asia, an issue scarcely addressed in historiography. De Sousa's main objective is to provide new empirical evidence, based upon western and eastern sources, to study Sephardim trade networks that operated in Manila and Macao. Arrival of European (mainly Portuguese and Spanish) merchants in Macao was an important factor that boosted local demand in South China for American silver. This led to chronic dependency that some might claim led to Chinese economic decline during Qing dynasty.

Von Glanh challenges «crisis» theories that assume economic decline of China's economy due to dependency on silver imports, instead of analysing silver as a trade commodity, with emphasis upon fluctuations in Chinese demand for silver in place of emphasis upon the supply-side of China's money supply. The Ming state during the Hongwu reign established paper money (宝钞băo chāo), and also bronze coins, as standard currency, while banning silver and gold money. The lack of supplies of copper shifted market demand to uncoined silver (sycee, 細絲xìsī) and domestic silver mining boomed during the $15^{\text {th }}$ century. Emperor Hogwu bans on foreign trade fostered smuggling trade and increase the demand for Japanese silver, and later American silver, coincided with the arrival of European (mainly Portuguese) to South China (Macao and Canton) and Japan in the mid of the $16^{\text {th }}$ century. This is the period of early formation of Iberian merchants networks, coinciding with Iberian union of crowns, during which time Spanish merchants established the Manila-Acapulco trade route linked to China, and Portuguese merchants profited mightily through exchange of Chinese goods (silk, tea, porcelain) for American silver via Macao, alongside other goods such as musk, gold, coral, European liquors (wines) and American crops (i.e. potato, sweet potato, corn, chili). Manila and Macao were the main trade nodes in the Pacific region that integrated Chinese and Japanese markets with the Americas and Europe.

According to Spanish memorials of the early $17^{\text {th }}$ century, quoted by von Glahn, profits gained through exportation of silver to China compensated for Spain's deficit in trans-Pacific trade. Local officials in Fujian 
and Guangdong insisted that the Court open foreign trade as they realised that Chinese importation of silver was highly profitable. Von Glahn states that the immediate effect of silver imports and foreign trade was a higher standard of living for local gentry, merchants, artisans and Chinese society in general. After the separation of Spain and Portugal in 1640s, repression of the sangleyes rebellion in Manila and also Dutch attacks are cited by some scholars as main causes for the decline in foreign silver imports into China and subsequent fall of the Ming dynasty. These are the so-called "crisis» theories (Chaunu 1962; Atwell 1982) which von Glahn challenges as rigid conceptualisations of the world economy and Ming China. Von Glahn challenges Atwell theoretically and empirically, arguing that there was only a small deficit of 4.4 per cent of silver imports to China, which did not have severe consequences for China's economy.

Through von Glahn's rich empirical evidence and the one by other authors in this volume, we can certainly assume that a new world economy scenario emerged when Iberian union of crowns ended in the 1640s, coinciding soon thereafter with the arrival of the Qing dynasty. These disruptions had short-term effects on quantities of silver imported into China, but there was no serious long-term breakdown. Official data on silver imports might indicate decrease, but effects of the smuggling trade involving silver imports into China have not been sufficiently documented. Silver imports continued through smugglers and «unofficial» institutions sometimes dominated chaotic markets. Uncontrollable and unregulated, much trade escaped regulations of the Qing court and Spanish monarchs, while corruption continued and silver accumulation continued by local gentry, merchants, artisans and commoners within China. Moreover, von Glahn's rich research argues against rigid interpretations of traditional scholarship based upon the analysis of silver flows in and out of China in aggregate terms without establishing typologies of silver and commodities.

\section{CONCLUDING REMARKS}

The five papers of this special issue of the RHE-JILAEH present comprehensive methodologies and cross-referencing of Chinese and European sources that document exchanges of American silver for Chinese goods in South China markets. The aim is to present new empirical evidence and new methodologies aimed at the reconstruction of trade statistics and end-market accumulations, and ultimately to approximate contraband trade in the markets of South China, the Americas and Europe. Contraband is a controversial issue that presents daunting empirical and methodological challenges, since official sources can provide only partial views of market realities. Nonetheless, analyses and uses of diverse 
sources discussed in this special issue demonstrate the possibility of better approximating «unofficial» trade in the context of institutions of Qing China and imperial Spain.

The social network analysis and goods (silks and silver) have been arranged in typologies to observe changing demand conditions over time, and how social actors (especially traders as mediators) motivated demand-side transformations is a core issue presented throughout papers of this volume. This demonstrates empirically how the "new» global history can be implemented through new theories, comparisons, case studies and primary sources in different languages. The polycentric approach of this «new» global history aims, as demonstrated in papers of this volume, to escape from misleading locations of core-periphery economic zones. On the contrary, our approach challenges prevalent Eurocentric and Sinocentric perspectives while decentralizing the world economic system into an integrated whole in which the traditional divide between developed and underdeveloped economies, and divisions between the West and East-still powerful historical traditional worldwide today-are shown to display subconscious biases that blur economic roles of world regions both historically and today.

\section{FINANCIAL SUPPORT}

This research has been sponsored and financially supported by GECEM (Global Encounters between China and Europe: Trade Networks, Consumption and Cultural Exchanges in Macau and Marseille, 1680-1840), a project hosted by the Pablo de Olavide University (UPO) of Seville (Spain). The GECEM Project is funded by the ERC (European Research Council) Starting-Grant, ref. 679371, under the European Union's Horizon 2020 Research and Innovation Programme, www. gecem.eu. The P.I. (Principal Investigator) is Professor Manuel Perez-Garcia (Distinguished Researcher at UPO). This work was supported by the H2020 European Research Council. This research has also been part of the academic activities of the Global History Network (GHN) in China www.globalhistorynetwork.com.

\section{ACKNOWLEDGEMENTS}

Received 03 September 2019. Accepted 05 September 2019.

I express my gratitude to all colleagues who participated in this special issue for their commitments, fruitful discussions and dialogue that make this project possible. The authors are part of the academic network of GECEM and GHN. Special thanks to GECEM team members such as Omar Svriz, Bartolome Yun-Casalilla, Marisol Vidales Bernal, Manuel 
Diaz Ordoñez, Jin Lei, Guimel Hernandez and Wang Li. I am grateful to collaborators and participants at GECEM network and GHN network events such as Dennis Flynn, Patrick O’Brien, Pat Manning, Nadia Fernandez de Pinedo Echevarria, Felix Muñoz, Joseph P. McDermott, François Gipouloux, Richard von Glahn, Debin Ma, among others. I also thank the editors of the RHE-JILAEH for believing in this project and for their support.

\section{REFERENCES}

Atwell, W.S. (1982): «International Bullion Flows and the Chinese Economy Circa 1530-1650». Past and Present 95, pp. 68-90.

Bonialian, M. (2014): China en la América Colonial. Bienes, Mercados, Comercio y cultura del consumo desde México hasta Buenos Aires. Buenos Aires-México: Biblos-Instituto Mora.

Boxer, C.R. (1958): «The Manila Galleon 1565-1815: The Lure of Silk and Silver». History Today, 8, pp. 538-547.

Chaunu, P. (1962): «Manille et Macao, face à la conjuncture des XVIe et XVIIe siècles». Annales: Économies, Sociétés, Civilisations 17.3, pp. 555-80.

Deng, K. (1999): Maritime Sector, Institutions and Sea Power of Premodern China. New York, London and West Port: Greenwood Publishing Group.

De Sousa, L. (2010): The Early European Presence in China, Japan, the Philippines and Southeast Asia (1555-1590). Macau: Macau Foundation.

De Zwart, P., and Van Zanden, J.L. (2018): The Origins of Globalization: World Trade in the Making of the Global Economy, 1500-1800. Cambridge: Cambridge University Press.

Drayton, R., and Motadel, D. (2018): «Discussion: The Futures of Global History». Journal of Global History 13, pp. 1-21.

ElLiot, J.H. (2002): Imperial Spain: 1469-1716. New York: Penguin Books.

FlynN, D.O. (2019): «Big History, Geological Accumulations, Physical Economics, and Wealth». Asian Review of World Histories 7, pp. 80-106.

FlynN, D.O., and GiRÁldEZ, A. (2008): «Born Again: Globalization's Sixteenth Century Origins (Asian/Global Versus European Dynamics)». Pacific Economic Review 13 (3), pp. 359-387.

Gipouloux, F. (2011): The Asian Mediterranean. Port Cities and Trading Networks in China, Japan and Southeast Asia, 13th-21st Century. Cheltenham and Northampton, MA: Edward Elgar.

Hausberger, B., and Ibarra, A. (2014): Introducción. Oro y plata en los inicios de la economía global. México: El Colegio de México.

LI, B. (2017): Guns and Account Books. Beijing: SDX Joint Publishing Company.

LI, Q. (2011): «Global History: A Representative of Those Reflecting on OccidentCentrism». China Social Sciences Today 9, p. 9.

LI, Q. (2018): Maritime Silk Road. Quebec-New Delhi: Royal Collins Publishing Group.

Liang Zhanjung (2006): "Comparing World History and Global History: A Chinese Scholar's View». Journal of Capital Normal University 3, pp. 1-5.

Liu, X. (2010): The Silk Road in World History. Oxford: Oxford University Press.

Liu Xincheng (2012): «The Global View of History in China». Journal of World History 23 (3), pp. 491-511. 
O'BRIEN, P. (2006): «Historiographical Traditions and Modern Imperatives for the Restoration of Global History». Journal of Global History, 1, pp. 3-39.

O'rourke, K., and Williamson, J.G. (2004): «Once More: When Did Globalisation Begin?» European Review of Economic History 8, pp. 109-17.

Perez-Garcia, M. (2016): «The Global Dimensions of «One Belt, One Road» Strategy in China-Latin America International Relations: Toward a Sustainable Economic Growth Model», in S. Cui, and M. Perez-Garcia (eds), China and Latin America in Transition Policy Dynamics, Economic Commitments, and Social Impacts. New York: Palgrave Macmillan, pp. 131-156.

Perez-Garcia, M., and De Sousa, L. (eds.) (2018): Global History and New Polycentric Approaches: Europe, Asia and the Americas in a World Network System. Palgrave Studies in Comparative Global History, Singapore: Palgrave-Macmillan.

Pomeranz, K. (2000): The Great Divergence: China, Europe, and the Making of the Modern World Economy. Princeton: Princeton University Press.

SuARez, M. (2018): «The Alternative Circuits of Silver: Lima and the Inter-Colonial Trade in the Pacific During the 17th Century», in J.I. Martinez Ruiz (ed.), The Spanish Empire in the World Economy (1580-1820). Sevilla: Editorial Universidad de Sevilla, pp. 239-260.

ToynbeE, A.J. (1934): A Study of History, vol I: Introduction: The Geneses of Civilizations. Oxford: Oxford University Press.

VAN Dyke, P.A. (2016): Merchants of Canton and Macao: Success and Failure in Eighteenth-Century Chinese Trade. Hong-Kong: Hong Kong University Press.

Wu Xiaodun (2005): «Do We Really Need a 'Global View of History'?». Xueshu Yanjiu [Academic Research] 1, pp. 5-15.

Yu, P. (2006): "Global History and National Historical Memory». Shixuelilunyanjiu [Historiography Quarterly] 1, pp. 18-30.

Yun-Casalilla, B. (2019): Iberian World Empires and the Globalization of Europe 1415-1668. New York: Palgrave Studies in Comparative Global History, Palgrave Macmillan.

Yuste Lopez, C. (2007): Emporios transpacíficos. Comerciantes mexicanos en Manila, 1710-1815. Mexico DF: UNAM. 